ORIGINAL ARTICLE

\title{
Investigation of perceived stress situations in university students during the corona virus outbreak process
}

\author{
YENER AKSOY 1 \\ ${ }^{1}$ Department of Sports Science, Ondokuz Mayıs University Faculty of Sport Samsun, Turkey. \\ Email: yeneraksoygsim@gmail.com
}

\begin{abstract}
Background: Stress is defined as the body's mental and physical action and reaction to any physical or psychological stimulus in order to achieve the necessary adaptation.

Aim: In this study, it was aimed to investigate the perceived stress situations of university students during the corona virus outbreak process.

Methods: The perceived stress scale filled by 489 university students was evaluated. Independent t-test, paired ttest, unidirectional variance analysis and LSD tests were used in statistical operations.

Results: Perceived stress is statistically different in both pre-epidemic and throughout the epidemic cases by gender ( $p<0.001)$. It was also found that the perceived stress was higher during the outbreak compared to the pre-outbreak situation $(p<0.001)$. There was a statistically significant difference between the perceived stress scores of the students who said that the sleep patterns of the students did not change, I slept more or less ( $p$ $<0.001)$. Stress level changed according to the state of doing sports $(p<0.001)$. There was no significant difference in stress scores between watching TV and watching corona virus news on the internet $(p>0.05)$. There was a significant difference in perceived stress scores in social media according to the frequency of exposure ( $p$ $<0.001)$.

Conclusion: During the corona virus epidemic, students' perceived stress levels increased. People who do not do sports were more affected by this process. Perceived stress situations have changed according to the level of exposure to coronavirus news on social media. In order to get rid of the stress of the corona virus epidemic, it is recommended to do sports, strengthen the immune system and be less exposed to scary news on social media. Keywords: Corona virus, perceived stress, student, sport
\end{abstract}

\section{INTRODUCTION}

Stress is defined as emotional, physical and cognitive reactions that threaten or disrupt one's daily social, emotional and cognitive functions. ${ }^{1,2}$ Stress is defined as the body's mental and physical action and reaction to any physical or psychological stimulus in order to achieve the necessary adaptation. ${ }^{3}$ Stress, as it is perceived, is a situation that occurs when the physical and mental limits of the organism are challenged and threatened in the face of anything that affects the organism. ${ }^{4}$ Stress reveals negative effects on human health. Stress also has a strong relationship with mental health. ${ }^{1}$ Stress is a negative emotional experience accompanied by predictable biochemical, physical, mental and behavioral changes that are directed towards changing the stressful situation or adapting to its effects. ${ }^{5}$ Stress has a causal role in the formation of fatal behaviors such as exposure to life events and suicide. ${ }^{6,7}$ Stress affects people's learning and memory. Stress is an expression used to describe the body's psychological and/or physiological response to situations that require re-adjustment of behavior. 8,9

The intensity of the stress people perceive and how they cope with it have a strong relationship with their physical and mental health. ${ }^{10,11}$ The long and intense duration of stressful situations or events may trigger depressive and anxiety symptoms in individuals. ${ }^{12,13}$ Stress in general, especially chronic stress, is considered effective in the development and acceleration of depression. Although the harmful effects of stress are well known, stress levels are high in the general population. ${ }^{14}$ While a pandemic causes sharp shocks to world economies and societies, it has negative effects on individuals. ${ }^{15,16}$

Factors such as housing conditions, adolescence problems, economic problems, interpersonal problems, problems related to the department of education and security can be counted as sources of stress in university students. ${ }^{17}$ The changes brought and made compulsory by the coronavirus epidemic naturally affected the career concerns of the young population who receive higher education and constitute the workforce of the future. ${ }^{18,19}$ On the one hand, the health-related risks created by the epidemic and, accordingly, the remote conduct of education and training activities, the slowing economic system, the closed businesses and the increasing unemployment rates may adversely affect the mental state of the youth. Stresses include perceived security, threat and risk of contamination, ignorance of the unknown, quarantine and imprisonment, stigma (a sign of shame associated with a particular situation, quality, or person), and social exclusion, as well as financial loss and job insecurity. ${ }^{20,21,22,23} \mathrm{He}$ found that doing sports is associated with a decrease in emotional stress. ${ }^{24}$ Stress affects performance negatively. ${ }^{25}$. Exercise and physical activity help to eliminate the negative mood caused by chronic stress. ${ }^{26}$ Doing sports not only contributes to the physical and social aspects, but also to the protection, development and psychological well-being of psychological health. $27,28,29$

In various studies in the literature, it has been determined that participation in sports protects and improves psychological health and reduces aggression. ${ }^{30,31,32}$ It has been determined that there is a decrease in the patience tendency of people during the 
corona virus process. ${ }^{33}$ Physical activity and sportive activities both facilitate coping with existing sources of stress and protect individuals against stress in general. ${ }^{34,44,45}$ In this study, it is aimed to investigate the perceived stress situations of people during the corona virus epidemic.

\section{MATERIAL \& METHODS}

Subjects: The participants consisted of young people studying at the university. The questionnaires were completed 6 months after the onset of the corona virus outbreak. A personal information questionnaire was also filled out by the participants. This personal information includes questions about believing in their immunity, sleeping, enjoying TV, being exposed to the corona virus on social media, restrictions or quarantine situations, and playing sports. After the erroneous or incomplete questionnaires were removed, the answers of 489 university students were evaluated. Questionnaires were filled on a voluntary basis. Those with chronic diseases and those who were infected with the virus were excluded from the study.

Data collection tool: Perceived Stress Scale (PSS): It is a measurement tool developed by Cohen et al., (1983) to measure how often stress symptoms occur. ${ }^{35}$ Consisting of 14 items in total, PSS is designed to measure how stressful a person's life is perceived to be. Participants evaluate each item on a 5-point Likert-type scale ranging from "Never (0)" to "Very often (4)". One of the options is required to be selected by taking into account the last 1 month period. There is no time limit for answering the scale. While 7 items in the scale are scored normally, 7 questions are scored in reverse order. A minimum of 0 and a maximum of 56 total points can be obtained. An increase in the total scores obtained indicates the excess of the individual's perceived stress, and the low total scores obtained indicate the low level of perceived stress. The Turkish adaptation of the scale was carried out by Eskin et al., (2013). ${ }^{2}$

Statistical analyses: SPSS 25.00 package program was used for statistical operations. To test whether the data are normally distributed, Kolmogorov-Smirnov test was performed and it was determined that the data showed normal distribution. Independent t-test, paired t-test, oneway analysis of variance and LSD tests were used for statistical operations.

\section{RESULTS}

Table 1 Comparison of Age, Height and Body Weights by Gender

\begin{tabular}{|c|c|c|c|c|c|c|}
\hline (2) & Sex & $\mathrm{N}$ & Average & St. Deviation & t-test & $p$ \\
\hline \multirow[t]{2}{*}{ Age (Year) } & Male & 254 & 21.30 & 2.93 & \multirow[t]{2}{*}{0,92} & \multirow[t]{2}{*}{1,03} \\
\hline & Female & 235 & 21.13 & 2.35 & & \\
\hline \multirow{2}{*}{$\begin{array}{l}\text { Height } \\
\text { (cm) }\end{array}$} & Male & 254 & 177.16 & 6.14 & \multirow[t]{2}{*}{$21,72^{* *}$} & \multirow[t]{2}{*}{0,001} \\
\hline & Female & 235 & 163.71 & 6.35 & & \\
\hline \multirow[t]{2}{*}{ Body weight (kg) } & Male & 254 & 73.43 & 8.59 & \multirow[t]{2}{*}{$17,42^{\star \star}$} & \multirow[t]{2}{*}{0,001} \\
\hline & Female & 235 & 59.63 & 9.28 & & \\
\hline
\end{tabular}

Table 2. Perceived stress scores according to the situation before the Corona virus and the situation during the epidemic process by gender

\begin{tabular}{|c|c|c|c|c|c|c|}
\hline 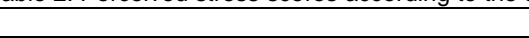 & sex & $\mathrm{N}$ & Average & St. Deviation & t-test & $\mathrm{p}$ \\
\hline \multirow{2}{*}{ Perceived stress before } & Male & 254 & 35.40 & 4.53 & \multirow{2}{*}{$-3,45^{\star *}$} & \multirow{2}{*}{0,0325} \\
\hline & Female & 235 & 37.10 & 4.41 & & \\
\hline \multirow[b]{2}{*}{ Perceived stress now } & Male & 254 & 36.59 & 4.71 & \multirow[b]{2}{*}{$-5,77^{\star *}$} & \multirow[b]{2}{*}{0,001} \\
\hline & Female & 235 & 39.86 & 4.30 & & \\
\hline Perceived stress versus pre-pandemic situation & Total & 254 & 36.22 & 4.53 & \multirow[b]{2}{*}{$-7,82^{* *}$} & \multirow[b]{2}{*}{0,001} \\
\hline Perceived stress epidemic order by situation & Total & 235 & 38.16 & 4.20 & & \\
\hline
\end{tabular}

$$
{ }^{* *} \mathrm{p}<0,001
$$

Table 3. Comparison of Stress scores according to sleep patterns during the epidemic

\begin{tabular}{|c|c|c|c|c|c|}
\hline Sleep status & $\mathrm{N}$ & Average & St. Deviation & F/LSD & $\mathrm{p}$ \\
\hline No change in sleep state (1) & 198 & 36.75 & 4.34 & \multirow{4}{*}{$\begin{array}{l}9,12^{* *} \\
1<2,3\end{array}$} & \multirow{4}{*}{0,001} \\
\hline I sleep more (2) & 213 & 39.37 & 4.63 & & \\
\hline I sleep less (3) & 78 & 38.45 & 4.43 & & \\
\hline Total & 489 & 38.16 & 4.20 & & \\
\hline
\end{tabular}

${ }^{* *} p<0,001$

Table 4. Comparison of perceived stress scores according to their immune perception status

\begin{tabular}{|l|l|l|l|l|l|l|}
\hline & & $\mathrm{N}$ & Average & St. Deviation & $\mathrm{F}$ & $\mathrm{p}$ \\
\hline \multirow{4}{*}{ immune status } & Strong & 304 & 37.91 & 5.33 & 0,78 & \\
\cline { 2 - 6 } & Partly strong & 148 & 38.54 & 5.05 & \\
\cline { 2 - 5 } & Weak & 37 & 39.18 & 4.36 & \\
\cline { 2 - 5 } & Total & 489 & 38.16 & 4.20 & \\
\end{tabular}

Table 5. Comparison of perceived stress scores according to the status of doing sports during the epidemic

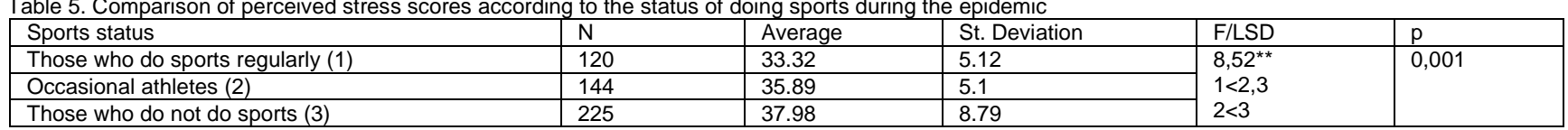

${ }_{* *} p<0,001$ 
Table 6. Perceived stress scores according to the use of watching television and following coronavirus news on the Internet and exposure to it on social media

\begin{tabular}{|c|c|c|c|c|c|c|}
\hline & & $\mathrm{N}$ & Average & St. Deviation & F/LSD & $p$ \\
\hline \multirow{3}{*}{ TV + internet } & $0-2$ hour (1) & 334 & 37.95 & 4.09 & \multirow[t]{3}{*}{0,89} & \multirow[t]{3}{*}{0,942} \\
\hline & 3-4 hour (2) & 110 & 38.59 & 4.40 & & \\
\hline & 5 hours and over (3) & 45 & 39.32 & 4.83 & & \\
\hline \multirow{5}{*}{$\begin{array}{l}\text { Exposure to information about the Corona } \\
\text { Virus on social media }\end{array}$} & Never+Once in a while (1) & 25 & 32.61 & 5.17 & \multirow{5}{*}{$\begin{array}{l}8,98^{\star \star} \\
1<2,3,4,5 \\
2<4,5 \\
3<4\end{array}$} & \multirow[t]{5}{*}{0,001} \\
\hline & Sometimes (2) & 73 & 35.80 & 4.45 & & \\
\hline & Usually (3) & 70 & 36.48 & 4.05 & & \\
\hline & Often (4) & 300 & 39.18 & 4.24 & & \\
\hline & Vey often (5) & 21 & 37.70 & 4.65 & & \\
\hline
\end{tabular}

${ }^{* *} \mathrm{p}<0,001$

\section{DISCUSSION}

In this study, it was determined that the height and body weights of the participants differed from each other according to gender $(\mathrm{p}<0.001)$.

There are many studies reporting that stress differs in terms of gender.17,36,37 In addition, there are studies stating that stress does not differ according to gender.38,39 It has been suggested that there are more studies showing that stress differs according to gender, and that the anxiety and stress levels of male students are lower than female students.36 For example, Misra et al., (2000) found that female students experience more stress than male students due to anger, internal and external pressure. 40 However, even when female students live at a lower level, they may seem more stressed than males.37 In this study, the perceived stress was statistically different according to gender in the scoring of the answers filled in both the preepidemic situation and the situation during the epidemic $(p<0.001)$. It was also found that the perceived stress was higher during the epidemic compared to the pre-epidemic situation (Paired t-test=-7.82; $\quad \mathrm{p}<0.001$ ). Women's perceived stress scores are higher than men's.

The coronavirus epidemic will affect our personality, the complex of emotions, thoughts, behaviors, goals and perspectives in the world.41 In this study, there was no change in the sleep patterns of the students during the epidemic, and a statistically significant difference was found between the perceived stress scores of those who said they slept more or less $(p<0.001)$. Those who stated that there was no change in their sleep state had a lower perceived stress score than those who stated that they slept more and less.

In this study, the difference in perceived stress scores according to their immunity perception status was not found significant $(p>0.05)$. Perceived stress scores did not change according to their perception of their own immunity.

Current studies have been conducted that indicate the positive effects of continuing regular physical activity or exercises on people's physical and mental health.32 Staying physically active contributes positively to the immune system.42 Therefore, being active during the quarantine process can help maintain health and fitness.32 In this study, it was determined that there was a significant difference in the stress levels of doing sports without gender discrimination during the epidemic $(p<0.001)$. During the epidemic, it is recommended that people do sports by following the hygiene conditions and being protected.

In a study, it was stated that news and statements about the Corona virus epidemic on social media prevented the deterioration of people's quality of life, but did not provide a change in their anxiety. 43 In another study, it was determined that exposure to the corona virus on social media during the epidemic process changed the level of anger.25 In another study, it was found that the patience status did not change significantly according to the hours of following the developments related to the Corona virus. In this study, no significant difference was found in stress scores between watching television and following the coronavirus news on the internet $(p>0.05)$. A significant difference was found in perceived stress scores according to the frequency of exposure to social media $(p<0.001)$.

\section{CONCLUSION}

The perceived stress levels of the students increased during the corona virus epidemic. People who do not do sports were more affected by this process. Perceived stress situations have changed according to the level of exposure to coronavirus news on social media. In order to get rid of the stress of the corona virus epidemic, it is recommended to do sports, strengthen the immune system and be less exposed to scary news on social media.

\section{REFERENCES}

1. Çevik A, Şentürk V. An overview of psychosomatic medicine and psychosomatic disorders in the historical process. Turkiye Klinikleri Journal of Psychiatry 2008; 1: 1-11

2. Eskin, M., Harlak, H., Demirkıran, F. and Dereboy, C. Turkish adaptation of the perceived stress scale: Validity and reliability analysis. New Symposium Journal 2013; 51(3), 132-140.

3. Tavlı F, Ünsal G. Evaluation of stress sources and coping attitudes of factory employees 2016; JAREN, 2:9-15.

4. Yildiran, I. Stress and relaxation techniques for coping with stress. Hacettepe University Faculty of Education Journal $1991 ; 6,175-189$.

5. Baum, A. "Stress, Intrusive Imagery, and Chronic Distress", Health Psychology 1990; 9(6), 653-675.

6. Pilowsky DJ, Keyes KM, Hasin DS Adverse childhood events and lifetime alcohol dependence. American Journal of Public Health 2008; 99: 258-263

7. Simmons LA, Havens JR, Whiting JB, Holz JL, Bada H Illicit drug use among women with children in the United States: 2002-2003. Annals of Epidemiology 2009; 19: 187-193.

8. Shors TJ. Stressful experience and learning across the lifespan. Annual Review of Psychology 2006; 57: 55-85.

9. Çetin S., İmamoğlu O. Investigation of stress levels according to the exercise behavior change stages of women, Progress in Nutrition 2021; 13(1);1-7. DOI 10.23751/pn.v23iS1.11590

10. Ataman, T. E. and Dag, I. Relationships between stressful life events, cognitive emotion regulation strategies, depressive symptoms and anxiety level. Clinical Psychiatry 2014; 17, 7-17.

11. Maner, F. and Aydın, A. Psychosociocultural factors in bulimia nervosa. The Thinker 2007; 20(1), 25-37. 
12. Hammen C. Stress and depression. Annual Reviewof Clinical Psychology 2005; 1, 293- 319.

13. Kendler, K.S., Hettema, J.M., Butera, F., Gardner, C.O. ve Prescott C.A. ife Event Dimensions of Loss, Humiliation, Entrapment, and Danger in the Prediction of Onsets of Major Depression and Generalized Anxiety. Archives of General Psychiatry 2005; 60,789-796.

14. Klaperski, S., von Dawans B, Heinrichs M. ve Fuchs, R. Effects of a 12-week endurance training program on the physiological response to psychosocial stress in men: a randomized controlled trial, Journal of Behavioural Medicine, 2014; 37(6), pp: 1118-33.

15. Macintyrea CR. On a knife's edge of a COVID-19 pandemic: is containment still possible? Public Health Res Pract. 30. 2020

16. Shigemura J, Ursano RJ, Morganstein JC, et al. Public responses to the novel 2019 coronavirus (2019-nCoV) in Japan: mental health consequences and target populations. Psychiatry Clin Neurosci. 2020; 74(4): 281-282.

17. Savcl, M. and Aysan, F. The Relationship Between Perceived Stress Level and Strategies for Coping with Stress in University Students. International Journal of Turkish Educational Sciences, 2014; (3), 44-56.

18. Mahmud, M.S., Talukder, M.U. and Rahman, S.M., Does 'Fear of COVID-19'trigger future career anxiety? An empirical investigation considering depression from COVID19 as a mediator. The International Journal of Social Psychiatry, (Early View) doi 2020; 10.1177/0020764020935488

19. Ceviz, N, Tektaş, N, Basmacı, G, Tektaş, M. Analysis of the variables affecting the anxiety levels of university students during the Covid 19 pandemic process. International Journal of Educational Researchers 2020; 3 (2), 312-329.

20. Achdut N, Refaeli T. Unemployment and psychological distress among young people during the covid-19 pandemic: Psychological resources and risk factors. International Journal of Environmental Research and Public Healt 2020; 17(19), 7163-7184.

21. Hamouche S. COVID-19 and employees' mental health: stressors, moderators and agenda for organizational actions [version 1; peer review: awaiting peer review] Emerald Open Research, 2020;

2:15 (https://doi.org/10.35241/emeraldopenres.13550.1)

22. Kılınçel, Ş, Kılınçel, O, Muratdağı, G, Aydın, A, Usta, MB Factors affecting the anxiety levels of adolescents in homequarantine during COVID-19 pandemic in Turkey. Asia Pacific Psychiatry 2020; e12406. doi: 10.1111/appy.12406

23. Liang L., Ren H., Cao R., Hu Y., Qin Z., Li C., Mei S. The effect of Covid-19 on youth mental health. Psychiatric Quarterly, 2020; 91, 841-852.

24. Steptoe A, Butler N. Sports participation and emotional wellbeing in adolescents. Lancet 1996; 347:1789-1792.

25. İmamoğlu, O., Doğan, E. Investigation of the Effect of Corona Virus Outbreak on Anger Levels According to Some Parameters, Turkish Studies 2020; 15(4), 555-563. https://dx.doi.org/10.7827/TurkishStudies.44383

26. Can, S. The determining of relationship between physical activity and perceived stress level in security service employees. Journal of Education and Training Studies 2019; 7(1), 149-155.

27. Sekban G.,Imamoğlu O. Investigation of life satisfaction and psychological well-being of university educated students in the coronavirus epidemic, Apuntes Universitarios, 2021; 11(4), 384 - 398, DOl:https://doi.org/10.17162/au.v11i4.819

28. Salar, B., Hekim, M., Tokgoz, M. Comparison of the emotional states of individuals aged 15-18 doing team and individual sports. Mehmet Akif Ersoy University Journal of Social Sciences Institute 2012 4(6), 123-135.
29. Şener O. A., \& İmamoğlu O. Investigation of University Students' Life Satisfaction Levels during Corona Virus Outbreak Process, 3. International Conference on Sports for All and Wellness Proceedings Book, (Ed: Erdal Zorba) 2020; 195-204. http://iecses.org/CongreDetayiEng.php?id=72

30. Dilek AN, İmamoğlu O, Erkin A.(2017).Aggression Levels of Spectators in Terms of Stages of Behavior Change and Gender, International Journal of Cultural and Social Studies (IntJCSS), 3, 73-82.

31. Harvey, S. B., Overland, S., Hatch, S. L., Wessely, S., Mykletun, A., Hotopf, M. Exercise and the prevention of depression: results of the HUNT Cohort Study. AmericanJournal of Psychiatry 2017; 175(1),28-36.

32. Sener O. A., \& İmamoğlu O. The well-being of university students during the corona virus epidemic process, 3. International Conference on Sports for All and Wellness Proceedings Books, (Ed: Erdal Zorba) 2020; 187194. http://iecses.org/CongreDetayiEng.php?id=72

33. Doğan, E. \& İmamoğlu, O. Investigation of Patience Trends in the Corona Virus Outbreak Process of University Students, Turkish Studies 2020; 15(4), 315324. https://dx.doi.org/10.7827/TurkishStudies.44382

34. Mumcu N., Mumcu H.E. The Effects of Sports on Stress and Happiness, Academician Publishing House 2019;

35. Cohen S, Kamarck T, Mermelstein R A global measure of perceived stress. Journal of Health and Social Behavior 1983; 24: 385-396.

36. Demir M. Investigation of the Relationship Between Problem Solving Skills, Perceived Stress and Life Satisfaction Levels of High School Students, Istanbul Sabahattin Zaim University Social Sciences Institute Educational Sciences Department Guidance and Psychological Counseling Master's thesis, Istanbul 2019

37. Özgan, H., Balkar, B., ve Eskil, M. Causes of Stress Perceived in Class by Education Faculty Students and the Effect of Personal Variables on Stress. Electronic Journal of Social Sciences, 2008; 7(24): 337-350.

38. Bilgel, N., Kabataş, B., Atalar, G., ve Gündüz, Y. Emotional State Study of Uludag University Faculty of Economics and Administrative Sciences Students. Paper presented at the 8th Turkish Econometrics and Statistics Congress. Inonu University, Malatya. 2007

39. Hevedanlı, Ö. ve Çakmak, A. An Investigation of the Anxiety Levels of the Biology Department Students of Education and Science and Letters Faculties in terms of Various Variables. Electronic Journal of Social Sciences 2014; 4(14): 115-127.

40. Misra, R., McKean, M., West, S., \& Russo, T. Academic Stress Of College Students: Comparison Of Student And Faculty Perceptions. College Student Journal 2000; 34(2):132-148.

41. Jeronimus, B.F. Personality and the Coronavirus Covid-19 Pandemic. University of Groningen Press 2020; 1-98.

42. Uzun M., İmamoğlu O. Exercise and Immunity in the Corona Virus Process, Multidisciplinary Research in Sports Science, (Editors: Gökmen Özen, Özdemir Atar), Efe Akademi Publications, Istanbul, 1st Edition 2020; ISBN: 978-625, Chapter 7,101-120

43. Yazıcı Y. \& İmamoğlu O. Investigation of quality of life and anxiety situations during the coronavirus outbreak process. Bozok International Journal of Sport Science 2021; 2 (1), 146-155.

44. Ilkım M. Çelik T., Mergan B.(2021) Investigation of Sports Management Students' Perceptions and Attitudes towards the COVID-19 Pandemic, Pakistan Journal Of Medical \& Health Sciences, Volume15 Issue 2 Page799-803,

45. Karaca Y., Ilkım M.,(2021) Investigation Of The Attitudes Distance Education Of The Faculty Of Sport Science Students In The Covid-19 Period, Turkish Online Journal Of Distance Education Volume22, Issue 4, Page114-129 